\title{
Ethics and Its Discontents: Evidence from Terrorism Research in North-Eastern Nigeria
}

\author{
Iro Aghedo ${ }^{1}$ \\ Department of Political Science, University of Benin \\ iro.aghedo@uniben.edu
}

\begin{abstract}
Terrorism and other forms of political violence have become a huge threat to human security, livelihoods and property in Nigeria in recent years. Though pervasive across the country, the North-East Geopolitical Zone has been the worst hit by insurgency since Nigeria's redemocratisation in 1999. This article examines the role of the researcher and their participants in areas affected by terrorism, and uses ethical principles as the framework of analysis. Following fieldwork-based experiential dilemmas in the terrorist environment (that is, where terrorists operate), this article argues that even though ethical principles are framed in general terms, their applicability is largely situational and contextdependent. Therefore, this article argues for a pragmatic situational ethical framework that gives 'voice' to respondents in North-Eastern Nigeria and similar terrorist environments.
\end{abstract}

\section{Introduction}

State-society relations in Nigeria have been violently conflictual in recent decades, especially during the country's tortuous transition from military dictatorship and since its return to civil rule in 1999. Although such violent relations are not totally new-as evidenced by similar cases in the First Republic (1963-1966), Second Republic (1979-1983), and during the aborted Third Republic (1992-1993) - their scale and frequency have increased in the Fourth Republic (1999-present). Across the country's six

\footnotetext{
1 The author would like to thank ARAS Editor Tanya Lyons for her very useful comments on an earlier draft of this article. Thanks are also due to Professors S.I. Ebohon and M.I.M. Abutudu of the Department of Political Science, University of Benin for their advisory role in the research. I am also grateful to my contact persons and research participants in the North-East of Nigeria.
} 
geopolitical zones (South-West, South-South, South-East, North-Central, North-West and North-East), ethnic militias and other violent non-state actors have emerged with different motivations and strategies to challenge state authority (Mustapha, 2009). The operations of the rebel movements have been concentrated within these geopolitical zones, rather than within particular states in the Nigerian federation.

In the South-West, the militancy of the Oodua People's Congress (OPC) was triggered by the alleged marginalisation of the Yoruba ethnic group in national politics, particularly as signaled by the annulment of the 12 June 1993 presidential election, which was believed to have been won by Yoruba business magnate, Chief M.K.O. Abiola (Nolte, 2007). In the South-South, the Niger Delta insurgent movements were motivated by grievances over the human and environmental insecurity engendered by the oil exploration activities of multinational corporations, and the injustice inflicted on the region by the state's inequitable distribution of oil wealth (Aghedo, 2015; Anugwom, 2005). The South-East is also not immune to violence, as exemplified by the activities of the Movement for the Actualisation of the Supreme State of Biafra (MASSOB) and the Indigenous People of Biafra (IPOB), as well as the intractable clashes between the Aguleri and Umuleri communities whose actors have sworn to continue to fight one another "even when they meet in heaven" (Onwuzuruigbo, 2013, p. 129).

Like the South, the sprawling Northern region has been enmeshed in multiple conflicts in recent years. In the North-Central region, especially in such hot-spots as Benue, Taraba and the Plateau States, violent ethnoreligious fault lines have been drawn between indigenes (native or autochthonous people in a state) and settlers (migrants from other states), Christians and Muslims, and even between herders and farmers, over which group has the right to what territory and control over socioeconomic resources (Harnischfeger, 2004).

The emergence of the Boko Haram terrorist group in 2002, its subsequent radicalisation of local populations from 2009, and its rapid movement across the region has heightened insecurity in the North-Eastern states of Borno, Yobe and Adamawa, and in several other states beyond the zone, including Kano, Kaduna and Katsina in the North-West and the Federal Capital Territory, Abuja, in the North-Central. Boko Haram's violent attacks include the use of arson, bank raids, mass abduction, hostage-taking, planting of landmines, detonation of improvised explosive devices, beheading, and suicide bombing, among others. The targets of the group's terrorist violence are wide ranging, including combatants and noncombatants, women and children, and private and public properties. In a 
well-known example, the group abducted 276 Chibok schoolgirls in April 2014, and have since deployed several women and teenage girls as suicide bombers (Aghedo, 2016; Agbiboa, 2014).

Although exact casualty figures are hard to come by, Boko Haramrelated violence has claimed lives wantonly (Agbiboa, 2014). Besides the grisly killings, the terrorism has also destroyed an enormous amount of private and public infrastructure. In Borno State, which has been the worst hit, a recent assessment carried out by government across 27 local councils revealed that Boko Haram insurgents have destroyed: over one million private homes; 5,335 classrooms and other school buildings; 201 health centres; 1,630 water sources; 665 municipal buildings, including council offices, prisons and police stations; 726 power distribution substations; as well as poisoned several ponds, river basins, and lakes (Vanguard, 2016). The core political motive of Boko Haram has been to make the government accede to its demands for the establishment of a theocracy based on Sharia laws and the abolition of symbols of modernity including Western education, democracy and the mass media (Aghedo, 2016; Agbiboa, 2015).

Unlike the low-intensity conflicts in the South, Boko Haram's terrorist activities have posed the gravest threat to Nigerian sovereignty since the 1967-1970 Biafran Civil War, prompting current President Muhammadu Buhari to make counter-terrorism a key public policy. Besides the risk to Nigeria's internal stability, the jihadist violence has also been a source of insecurity for neighbouring states especially Niger, Chad and Cameroon. This growing 'internationalisation' and 'territorialisation' of the conflict could foreshadow danger beyond the sub-region, as captured and ungoverned territory could be penetrated and used as a launching ground for more devastating attacks by other terrorist organisations, such as those linked to al-Qaeda and the Islamic State. Terrorism in the region has also triggered terrible internal displacement and a massive refugee crisis.

The pervasiveness and huge cost of Boko Haram's terrorism has generated enormous local and international media coverage aimed at understanding the motives and drivers of the group. Although terrorism research is relatively new in Nigeria, academic interest in the subject has been impressive, albeit polarised between scholars who see terrorism as a product of religious extremism, including political Islam, (Adesoji, 2010) and others who emphasise the role of human insecurity, such as poverty, unemployment and poor education (Forest, 2012). However, while Boko Haram-related threats to the Nigerian state and sub-regional security have by necessity attracted the interests of media professionals (Johnson, 2011), policy analysts (Terrorism Prevention Amendment Act, 2013) and scholars 
(Sulemana, 2014), the challenges posed by the violence to researchers and those researched have received little or no attention thus far.

This article attempts to fill this gap by shedding some light on the dilemmas involved in applying ethical principles (those usually required of academics when doing research with human subjects) while undertaking terrorism research in North-Eastern Nigeria. The article argues that even though ethical values - such as those emphasising the physical security of the researcher and participants, informed consent, objectivity, anonymity, confidentiality and justice-are framed in general terms, their applicability is largely situational, context-dependent and varies across cultures. As a result, despite rhetoric regarding the universality of ethical values, total adherence to such norms affects the research and sometimes renders ethical conduct terribly problematic. This article therefore challenges mainstream thinking about ethical research.

Clearly these concerns are not peculiar to the North-East of Nigeria as shown by fieldwork challenges in the Niger Delta (Oriola \& Haggerty, 2012); apartheid South Africa (Goduka, 1990); Northern Ireland (Lundy \& McGovern, 2006); the Middle East (Romano, 2006); and the West Bank and Occupied Territories (Chatin, 2003) amongst others. However, I demonstrate that the experience of North-Eastern Nigeria is peculiar because of its cyclical sectarian conflicts; high rate of civilian victimisation; and abysmal levels of mass poverty, illiteracy and lack of basic social amenities which are higher than the national average (Suleiman \& Karim, 2015; Sodipo, 2013). These debilitating realities accentuate the researcher's dilemma.

For this article, I draw on my own research experiences in the Northern Region of Nigeria, which involved undertaking informal interviews with victims of violence, especially the almajirai (itinerant Quranic pupils) and talakawa (the downtrodden) (Aghedo, 2016; Aghedo, 2014). The aim of the studies was to ascertain the motivations behind Boko Haram's rebellion and the affinities between the group's activities and the Maitatsine urban revolt of the 1980s that resulted in over 10,000 fatalities. Furthermore, I was involved in conducting two survey studies in 2012 (for two weeks) and 2013 (for six weeks) on Boko Haram terrorism (Aghedo \& Osumah, 2012; Aghedo \& Osumah, 2014). During these research engagements, some of the norms of the scientific approach were difficult to observe, as revealed in the few cases discussed below.

At the University of Benin, where I work as a lecturer, all research is filtered through a Research and Publication Committee, which regulates and ensures compliance with ethical requirements. In line with this, I 
applied for and received ethics approval for this study. After my initial application for ethics approval, I was invited to defend my research proposal before the Committee. They questioned different aspects of the proposal and finally warned me not to engage in any unethical practice that would present the University in a bad light. There is no issuing of certificates of approval or ethics approval numbers as in many western universities. Nonetheless, individual researchers such as myself, do ensure strict compliance with universal ethical norms. During my research I also sought the expert advice of colleagues in my university department for further guidance while in the field, as well as relied on the advice of a number of contact persons in the North-East for practical exigencies.

\section{Ethical Research: Meaning, Principles and Discontents}

Social scientific research represents a special and unique way of expounding on group life and is crucial in knowledge production. Further, ethics play a fundamental role in the success or failure of social research. As a philosophical concept, ethics is principally "concerned with matters of good and bad, right and wrong, duty and obligation, and moral responsibility” (Hospers, 1967, p. 566). Sometimes concerns and conflicts arise over the proper way to conduct social research. In response to these ethical dilemmas, there are certain norms that guide the research process from its initiation through to data collection, analysis and finally to the publication of findings. The rationales for ethical research are varied, including to: protect participants' rights and privacy; guarantee the rights of others, including the public, to know; protect the researcher against litigation and keep the "doors open for future generations of researchers" (Harrison, 2001, p. 103).

The history of research ethics dates back to the Nuremberg Code, which was adopted as a result of Nazi war crimes during the Second World War, in particular, the cruelty that characterised experiments in concentration camps. Following the Nuremberg Code, certain ethical principles were designed as a guide for any research involving human subjects. According to Smyth and Williamson (2004), following the declaration of these principles "non-therapeutic research could not be conducted without the informed consent of the individual, irrespective of the benefits to wider society” (p. 6). While it is the case that issues in clinical research ethics are determined by consequentialist outcomes, those in social research are largely context-specific and thus the risk to human subjects in social research are of a different order to those in clinical studies. Nevertheless, they remain ethically problematic and relevant (Lyons, 2009). 
Research ethics has evolved in the last few decades in the West where ethical research issues are now discussed 'up front', especially in the clinical and social sciences. In the United Kingdom, for example, the Economic and Social Research Council (ESRC) has been at the forefront of the crusade for ethical research. In 2005, the ESRC drew up a framework of six fundamental principles that should guide the complex and often conflicted relationship between the researcher and the researched. The core principles included those of: integrity and quality; full disclosure about the research to research staff and subjects; confidentiality and anonymity; voluntary participation; avoidance of harm to participants; and disclosing conflicts of interest (ESRC, 2005). Many universities across the world now have their own research ethics policies and committees through which research is filtered before it is carried out. However, while there may be differences across institutions, ethical codes have been far more developed in the Global North than in the South. For example, while most firstgeneration universities in Nigeria have ethics committees, they are largely unable to control research processes thoroughly.

The six ethical principles discussed and analysed below are drawn from the British code as encapsulated in the 2005 ESRC framework. While the British code is by no means exhaustive, it does contain some of the most problematic principles to apply in conflict zones. Another justification for the analysis of these six principles is that they are also the primary ones applicable in most Nigerian universities, perhaps because of the country's colonial links to Britain. I juxtapose these six ethical principles with my practical research experiences in North-Eastern Nigeria, with the aim of highlighting the dilemmas inherent in their application in terrorist environment.

(i) Principle of safety or security: This ethical guideline admonishes that social research must avoid harm to those studied, the researcher and those affected by the research. Therefore, social research must be initiated, designed, conducted and disseminated in a way that manages risk to life, thereby guaranteeing the physical security of all those involved (Smyth, 2001). Thus, the researcher must adequately consider both the benefits and harms that may accrue to all stakeholders. This is particularly crucial for terrorism studies, because conducting research in conflict zones entails enormous risks for all involved, and the researcher must be conscious of likely dangerous areas before venturing into the field. Those who conduct such research must be diplomatic, honest, or non-committal on sensitive issues knowing full well that "conflict zones are not places of free 
intellectual debate and objective discourse” (Romano, 2006, p. 440). In addition, such researchers should avoid carrying or disseminating compromising documents in order to ensure their security and that of their informants.

(ii) Principle of informed consent: According to Goduka (1990), three dimensions are inherent in the principle of informed consent, namely, knowledgeability, voluntary participation and competent choice. This means that research participants must be given all necessary information about the research project so that they can participate in the process freely and make informed choices (Thorne, 1980). The issue of informed consent goes beyond data collection and includes research participants being given an opportunity to review interview transcripts and delete or anonymise anything they do not want to be included (Smyth, 2004). To ensure informed consent and mitigate concerns about deception and possible litigation, research participants should be made known of their rights, including the fact that they can stop or even withdraw from the research project at any time.

(iii) Principle of objectivity: In conformity with the demands of positivism, social researchers are enjoined to be open and honest in the research process, whether in selecting respondents (sampling), getting information from them (for example, using survey methods) or analysing their views. Social researchers must manage sensitive information objectively and without any bias. Researchers must consciously work to avoid prejudice because their identity - including their religious and ideological leaningscould have "implications for the way the research is conceptualized, carried out, analyzed and subsequently used” (Smyth, 2001, p. 7). Some people believe that it is more difficult for insiders to carry out objective research in their own environment than it is for outsiders, who are contextually detached by virtue of their identity. Such distinctions usually take the form of race, regionalism, nationality, ethnicity, religion, class, etc.

(iv) Principle of anonymity: This relates broadly to concealing the identity of research participants for their own safety. The researcher has an ethical duty to protect his/her sources. Usually, anonymity is achieved through the use of pseudonyms, aggregation of responses, use of percentages, etc. Anonymisation can also take the form of altering biographical details so as to conceal the identity of participants. Transcripts of interviews can be sent to respondents for approval and whatever they request as 'off-the-record' be 
so treated. Related to anonymity is the issue of confidentiality, which relates more to privacy and especially how data is used (Wiles, Charles, Crow, \& Heath, 2006).

(v) Principle of neutrality: This principle bids researchers to maintain a certain level of detachment from their informants or those they study. That is, like natural scientists, social researchers are largely believed to be able to examine the objects of their inquiry from an "external vantage point" and with a great deal of alienation (Hermann, 2001, p. 78). The insistence on neutrality is informed by the fact that its absence could result in identification with the research subjects, a situation that could have a detrimental effect on the validity of the research. To ensure neutrality, researchers, and especially those working on sensitive issues such as conflict, refugee crises and terrorism, are normally admonished to have a certain detached positionality and avoid taking sides on national debates in the field (Oriola \& Haggerty, 2012). In addition, the language of such researchers must be neutral and devoid of labelling because, in a volatile society such as Nigeria, ethno-religious and sectional sentiments could be read into a researcher's viewpoint by out-group members.

(vi) Principle of justice: This norm is anchored on the 'unspoken contract' between researchers and the researched. It entails ensuring that research participants are not disadvantaged by their involvement in the research process. Indeed, those researched sacrifice their time, energy and sometimes even risk their lives in the research process. Rather than being seen as partners or co-participants, they are often unrewarded and neglected. The principle of justice raises the issue of fairness and enjoins the researcher to fulfill his/her side of the bargain in research collaboration by taking the subjective needs of research participants seriously. According to Kappler (2013):

...there is a need to embed a concern about the productivity of knowledge for those helping to produce it in our disciplines and institutions. Knowledge should not only build a researcher's career or improve the publication output of a university, but it should yield benefits for our partners in the field (p. 137).

Since most people in conflict zones lack influence, the researcher is enjoined to give them a voice. Also, research outcomes and findings usually 
have more benefits if they are published in outlets that guarantee a widespread readership so that people, including policy makers, will have easy access that may help create awareness and mitigate further violence. As Smyth (2001) stated, it is ethically questionable to conduct research on human beings without a consideration of their "subjective needs and the impact of the research on their situation" (p. 5). Thus, the researcher should endeavour to consider the needs of research participants in addition to their academic goals.

These six principles of safety, informed consent, objectivity, anonymity, neutrality and justice are crucial guidelines for most research projects. Adherence to them is particularly important in terrorism research because of the largely insecure environment in which studies take place. In fact, any breach of the principles could endanger the lives of both researchers and their collaborators.

Nevertheless, despite the dynamic evolution and significance of research ethics, they have often come under attack. Some scholars have argued that the social sciences are low risk and therefore do not need to be regulated by research ethics committees (e.g., Dingwall, 2006). Some have been totally dismissive of ethical frameworks, labelling them as 'empty ethics' (Corrigan, 2003) which "impose silly restrictions” (Schrag, 2011, p. 122). Despite the criticisms, the social scientific community has remained committed to the applicability of ethical codes. In fact, Neuman (2003) admonishes that "the researcher has a moral and professional obligation to be ethical, even when research subjects are unaware of or unconcerned about ethics" (p. 116). Against the backdrop of incessant conflicts in Africa, Osaghae and Robinson (2005) rightly emphasised the need for research ethics on the continent when they noted that "ethical considerations ought to be central to conflict research in Africa, but so far they have not received the attention they so clearly deserve” (p. 3). However, adhering to the ethical norms is challenging in some environments on the continent as North-Eastern Nigeria exemplifies.

\section{Ethics and the Dilemmas of Terrorism Research in the North-East}

In this section, I reveal some of the dilemmas I faced in applying the above ethical principles to my terrorism research in the North-East region of Nigeria. To ensure clarity, I have done the analysis systematically in relation to the principles discussed above.

(i) Principle of safety or security: As stated earlier, this principle enjoins the researcher to avoid bringing harm upon themselves and those researched. 
Avoiding harm in the North-East of Nigeria is problematic because Boko Haram insurgents deliberately target persons (including researchers) who subscribe to modernity, secularity and an open society. For example, the terrorists victimize those who gather information as evidenced by the suicide bomb attacks on the offices of This Day, The Sun, and The Moment newspapers in Abuja and Kaduna in April 2012 which killed seven people (Human Rights Watch, 2012).

Several journalists have also been killed in the line of duty in northern Nigeria including: Channels TV journalist Enenchi Akogwu in Kano on 20 January 2012; Highland FM journalist Nansok Sallah in Plateau State on 18 January 2012; and The Scope journalist Samson Boyi in Adamawa on 5 November 1999, amongst others (Olatunji, 2014). While academic research and journalism are different, they are nevertheless similar with respect to information gathering and harm exposure (Rafferty, 2004).

Another source of risk emanates from government security forces who sometimes mistake academic researchers for terrorists. In 2012, I was taken in for questioning by two undercover police in Kano when I began research on the similarities and differences between the Maitatsine urban revolt, which broke out in the city in December 1980, and the contemporary Boko Haram movement (see Aghedo, 2014). The police identified themselves and led me to the station where I was interrogated over the motivations for my research for approximately two hours. It took the telephone intervention of my contact person and well-known retired police officer in the state before I regained my freedom. I was later told by one of the undercover police that it was my identity as a Southerner and especially my mode of dress that attracted their attention. Although I was wearing a pair of black trousers and a shirt made of asoke - a traditional cloth largely produced and worn by Yoruba people in the South-membership of the terror movement rarely included southerners. Also, though familiar with the North, I was unaware that my mode of dress could lead the police to mistake me for a terrorist. In any case, since this experience, I have been wearing the kaftan - a dress worn by most male Northerners-during my research visits.

In addition, harm to research participants could be indirect and difficult to handle. Considering the horrors perpetrated by Boko Haram, part of my research in the North-East necessarily involved participants revisiting past sorrowful events which made some of them break down in tears. Such harmful experiences often lead to what Lundy and McGovern (2006) have described as "secondary traumatization" (p. 56).

I experienced a dilemma as to how to handle the psychology of my distressed research participants, especially in remote areas where there were 
no counselling services. Since I had no skills in counselling, I had to rely on common sense. For example, I referred the student who told me that he was orphaned by Boko Haram terrorism in Damaturu, Yobe State, to the state ministry of education for guidance on how to get a scholarship to continue his schooling. For the middle-aged man who lost his only child in Bama, Borno State, I assured him that Allah would provide another child. However, for the inconsolable Igbo woman who lost her husband at the Nyanya bomb attack in Nasarawa State, I considered it best to stop the interview.

(ii) Principle of informed consent: This ethical principle enjoins researchers to inform research participants of their rights, including their freedom to withdraw from the research process at any time, as well as to seek their agreement in all issues related to their participation. Some of my respondents were illiterate, so they did not know much about informed consent. In fact, some of them told me that they had not heard of the principle before. To enable them to make sense of the research and their rights, I had to rely on interpreters who spoke to them in their mother tongue (Hausa or Kanuri). Despite the financial burden imposed by the use of interpreters, I was heartened that the participants were able to understand their role in the research exercise.

(iii) Principle of objectivity: In line with this principle, researchers are bidden to be open and honest in every aspect of the research process. However, such openness could also be used against the researchers in ethno-religiously segmented societies as my experience reveals. A lecturer at the Bayero University, Kano, asked me about my religious identity during an interview. I told him that I was a Christian. Having introduced myself earlier as a lecturer from the University of Benin, he knew I was from Southern Nigeria. In the course of the interview, he blamed the emergence of the terrorism on the inadequate economic development of the North. After agreeing with him, I pointed out that some analysts believed that religion also played a role in the radicalisation of the conflict. He retorted, "you are talking that way because you are a Christian Southerner". Implicitly, he saw me as biased because of my identity. I explained to him that as an academic researcher my identity had no influence on the objectivity of my research.

Obviously, labelling me as a 'Christian Southerner' was a reference to the intractable tension between the predominantly Christian South and the primarily Muslim North in the Nigerian federation. My experience shows 
that it is not only foreign researchers (those from other countries or races) that can be seen as outsiders. Even as an insider (Nigerian) researcher, my regional and religious identity positioned me as biased and untrustworthy in my own country. This also confirms the findings of Ergun and Erdemir (2010) and Oriola and Hergerty (2012) that in a violently segmented society a researcher's status in the field can be fluid and therefore negotiable; that one can be an insider in a foreign land and an outsider in one's own country. Indeed, Paden (2015) noted that the politicisation of ethnoreligious identity of individuals is a major precipitant of conflict in Nigeria and, as my case reveals, a source of challenge for Christians who research Muslim areas.

(iv) Principle of anonymity: Broadly, this ethical value is aimed at protecting the research participants' identities to ensure confidentiality. Besides the argument that excessive anonymisation of original viewpoints could "weaken the scientific value of the researcher's evidence and arguments" (Schnabel, 2005, p. 33), my experience in the North-East shows that while some research participants want their identity concealed, others want theirs known. This situation placed me in a dilemma because I knew that their lives could be endangered if their identities were made known. Therefore, I used interpreters to explain to them that their names would not be reported. I then expressed some sensitive views in the third person and aggregated others statistically in percentages.

(v) Principle of neutrality: To avoid taking sides, researchers are asked to maintain a certain level of distance from those they study. But as explained earlier, maintaining professional neutrality in the face of stories of the horrific attacks perpetrated by Boko Haram can be challenging. For example, while I empathised with the victims, I felt my primary responsibility as a researcher was to explain the terrorism and not necessarily to assess its rightness or wrongness, and for this reason I reckoned that maintaining a certain level of distance was critical. Further, in line with the saying that 'one person's terrorist is another person's freedom fighter', I felt that the perpetrators could also have their own stories to tell about why they did what they did. With this balanced mindset, I was able to listen to some of the heartbreaking stories of victims' trauma and pains.

(vi) Principle of justice: This ethical value is aimed at ensuring fair treatment for research participants, who sacrifice their time, energy and sometimes even risk their lives to participate in the research process. 
Following Neuman's (2003) call for researchers to 'give voice' (telling the story of a specific group in order to enhance its visibility) to marginalised groups in society and Kezar's (2003) admonition that action research should "challenge [the] power structures" (p. 395) that circumscribe the humanity of poor people, I felt the need to use my research to influence public policy in a way that could ameliorate the sufferings of the almajirai (itinerant Quranic pupils) and talakawa (the downtrodden). Indeed, as Lundy and McGovern (2006) rightly argue, "in situations where political violence has occurred and marginalized groups have experienced social injustice, it is ethically impossible and morally reprehensible for social researchers to remain detached and silent” (p. 49). As an academic researcher, however, I had neither political connections nor the resources to alleviate the deprivations of my research participants. Therefore, to achieve the goal of giving voice, I appeared on six national television shows (including on the Nigerian Television Authority and Edo Broadcasting Service) to highlight the plight of the almajirai and talakawa and their vulnerability to terrorist radicalisation.

Certainly publishing research findings in outlets that guarantee a large readership is also part of giving back to research participants. Even though many of my research participants are barely literate, I nevertheless carefully targeted free-access journals or those whose readership is mostly African for publication of my research findings. Though these journals are published abroad, their readership includes foreign governments, donor agencies and international civil society organisations. As such, publishing in them is crucial for creating awareness, attracting foreign aid and ultimately helping to reduce further violence against my research participants.

\section{Conclusion}

This article has revealed some inherent contradictions in applying ethical principles to terrorism research in North-Eastern Nigeria. The lessons gleaned from the ethical dilemmas arising from my fieldwork experiences can be encapsulated as follows. First, I have learnt that even though research norms such as ethical principles are framed in universal terms, their application is largely situational as they are influenced by contextual socio-economic conditions. Also, harassment and security threats faced by both the researcher and the researched can emanate from insurgents and state troops alike. I have also learnt that those researching the terrorist environment should not take their familiarity with research sites 
for granted as they still need a lot of information on local culture (for example, appropriate styles of dress).

Be that as it may, research ethics remain vital despite the practical challenges involved in keeping to the guidelines. As a result, this article argues for researchers' self-regulation and pragmatic situational approaches to come to terms with ethical dilemmas, especially 'giving voice' in order to enhance researcher-respondent rapport. As Neuman (2003) rightly notes "researchers face pressures to build a career, publish, advance knowledge, gain prestige, impress family and friends, hold on to a job, and so forth" (p. 118). Despite these pressures, this article recommends a balance between the researcher's academic goals and the overall positive impact on those studied.

\section{References}

Adesoji, A. (2010). The Boko Haram uprising and Islamic revivalism in Nigeria. Africa Spectrum, 4(2), 95-108.

Agbiboa, D. (2014). Peace at daggers drawn? Boko Haram and the state of emergency in Nigeria. Studies in Conflict and Terrorism, 37(1), 4167.

Agbiboa, D. (2015). State responses to insurgency in Nigeria. In J. I. Lahal \& T. Lyons (Eds.), African frontiers: Insurgency, governance and peacebuilding in postcolonial states (pp. $\mathrm{x}-\mathrm{xx}$ ). Farnham, Surrey: Ashgate Publishing Ltd.

Aghedo, I. (2014). Old wine in a new bottle: Ideological and operational linkages between the Maitatsine and Boko Haram revolts in Nigeria. African Security, 7(4), 229-250.

Aghedo, I. (2015). Sowing peace, reaping violence: Understanding the resurgence of kidnapping in post-amnesty Niger Delta, Nigeria. Insight on Africa, 7(2), 137-153.

Aghedo, I. (2016). Boko Haram. In R. C. Martin (Ed.), Encyclopedia of Islam and the Muslim world (2nd ed.) (p. 177). Michigan: Charles Scribner's Sons/Gale, Cengage Learning.

Aghedo, I., \& Osumah, O. (2012). The Boko Haram uprising: How should Nigeria respond? Third World Quarterly, 33(5), 853-869.

Aghedo, I., \& Osumah, O. (2014). Bread, not bullets: Boko Haram and insecurity management in northern Nigeria. African Study Monographs, 35(3\&4), 205-229.

Anugwom, E. (2005). Oil minorities and the politics of resource control in Nigeria.Africa Development, 30(4), 87-120. 
Chatin, J. (2003). 'I wish he hadn't told me that': Methodological and ethical issues in social trauma and conflict research. Qualitative Research, 13(8), 1145-1154.

Corrigan, O. (2003). 'Empty ethics': The problem with informed consent. Sociology of Health and Illness, 25(7), 768-92.

Dingwall, R. (2006). Confronting the anti-democrats: The unethical nature of ethical regulation in social science. Medical Sociology Online, 1, 51-58.

Economic \& Social Research Council (ESRC) (2005). Research ethics framework. Swindon: ESRC.

Ergun, A., \& Erdemir, A. (2010). Negotiating insider and outsider identities in the field: 'Insider' in a foreign land; 'outsider' in one's own land. Field Methods, 22(1), 16-38.

Forest, J. (2012). Confronting the terrorism of Boko Haram in Nigeria. Joint Special Operations University (JSOU) Report, 12-5. Florida: JSOU.

Goduka, I. V. (1990). Ethics and the politics of field research in South Africa. Social Problems, 37(3), 329-430.

Harnischfeger, J. (2004). Sharia and control over territory: Conflicts between 'settlers' and 'indigenes' in Nigeria. African Affairs, 103(412), 431-452.

Harrison, L. (2001). Political research: An introduction. London and New York: Routledge.

Hermann, T. (2001). The impermeable identity wall: The study of violent conflicts by insiders and outsiders. In M. Smyth \& G. Robison (Eds.), Researching violently divided societies: Ethical and methodological issues (pp. 77-91).Tokyo: United Nations University Press.

Hospers, J. (1967). An introduction to philosophical analysis. London: Routledge.

Human Rights Watch (2012). Spiraling violence: Boko Haram attacks and security force abuses in Nigeria. https://www.hrw.org/ report/2012/10/11/spiraling-violence/boko-haram-attacks-andsecurity-force-abuses-nigeria

Johnson, T. (2011). Boko Haram. http://www.efr.org/africa/bokoharam/p25739?cid=nlc-public-the_world_this_week-link7-.

Kappler, S. (2013). Coping with research: Local tactics of resistance against (mis-)representation in academia. Peacebuilding, 1(1), 125-140. 
Kezar, A. (2003). Transformational elite interviews: Principles and problems. Qualitative Inquiry, 9(3), 395-415.

Lundy, P., \& McGovern, M. (2006). The ethics of silence: Action research, community 'truth-telling' and post-conflict transition in the North of Ireland. Action Research, 4(1), 49-64.

Lyons, T. (2009). Globalisation, failed states and pharmaceutical colonialism in Africa. Australasian Review of African Studies, 30(2), 68-85.

Mustapha, A. R. (2009). Nigeria since 1999: A revolving door syndrome or the consolidation of democracy? In A. R. Mustapha \& L. Whitfield (Eds.), Turning points in African democracy (pp. x-xx). Oxford: James Currey.

Neuman, L. W. (2003). Social research methods: Qualitative and quantitative approaches (5th ed). Boston: Allyn and Bacon.

Nolte, I. (2007). Ethnic vigilantes and the state: The Oodua People's Congress in south-western Nigeria. International Relations, 21(2), 217-235.

Olatunji, R. W. (2014). Media freedom for a better future: Shaping the post2015 development agenda. The Guardian, May 26, 12-14.

Onwuzuruigbo, I. (2013). 'Even if we meet in heaven we will fight': British colonial policies and Aguleri/Umuleri conflicts in southeastern Nigeria. Journal of Asian and African Studies, 48(2), 129-144.

Oriola, T., \& Haggerty, K. D. (2012). The ambivalent insider/outsider status of academic 'homecomers': Observations on identity and field research in the Nigerian Delta. Sociology, 46(3), 540-548.

Osaghae E., \& Robinson G. (2005). Introduction. In E. Porter, G. Robinson, M. Smyth, A. Schnabel \& Osaghae E. (Eds.), Researching conflict in Africa: Insights and experiences (pp. 1-5). Tokyo: United Nations University.

Paden, J. (2015). Religion and conflict in Nigeria: Countdown to the 2015 elections. Washington, DC: United States Institute of Peace.

Rafferty, J. (2004). Interviewing: The unspoken compact. In M. Smyth \& E. Williamson (Eds.), Researchers and their 'subjects': Ethics, power, knowledge and consent (pp. 121-136). Bristol: The Policy Press.

Romano, D. (2006). Conducting research in the Middle East's conflict zones. PS: Political Science and Politics, 39(3), 439-441.

Schnabel, A. (2005). Preventing and managing violent conflict: The role of the researcher. In E. Porter, G. Robinson, M. Smyth M., A. Schnabel 
\& E. Osaghae (Eds.), Researching conflict in Africa: Insights and experiences (pp. 24-43).Tokyo: United Nations University.

Schrag, Z. (2011). The case against ethics review in the social sciences. Research Ethics, 7(4), 120-131.

Smyth, M. (2001). Introduction. In M. Smyth \& G. Robison (Eds.), Researching violently divided societies: Ethical and methodological issues (pp. 1-12).Tokyo: United Nations University Press.

Smyth, M. (2004). Using participative action research with war-affected populations: Lessons from research in Northern Ireland and South Africa. In M. Smyth \& E. Williamson (Eds.), Researchers and their 'subjects': Ethics, power, knowledge and consent (pp. 137-156). Bristol: The Policy Press.

Smyth, M., \& Williamson, E. (2004). Introduction. In M. Smyth, \& E. Williamson (Eds.), Researchers and their 'subjects': Ethics, power, knowledge and consent (pp. 1-16). Bristol: The Policy Press.

Sodipo, M. O. (2013). Mitigating radicalism in northern Nigeria. Africa Security Brief, 26, www.africacenter.org.

Suleiman, M. N., \& Karim, M. A. (2015). Cycle of bad governance and corruption: The rise of Boko Haram in Nigeria. SAGE Open, 5(1), 111.

Sulemana, M. (2014). Centenary of failure? Boko Haram, jihad and the Nigerian reality. Australasian Review of African Studies, 35(2), 6987.

Thorne, B. (1980). 'You still takin' notes'?: Fieldwork and problems of informal consent. Social Problems, 27(3), 284-297.

Vanguard Newspaper. (2016). Boko Haram destroyed 1m houses in Borno - Shettima, 16 March. www.vanguardngr.com/2016/03/boko-haramdestroyed-1m-houses-borno-shettima/

Wiles, R., Charles, V., Crow, G., \& Heath, S. (2006). Researching researchers: Lessons for research ethics. Qualitative Research, 6(3), 283-299. 